\title{
PENGARUH PENGGUNAAN PATI BIJI CEMPEDAK (Arthocarpus champeden Lour) SEBAGAI BAHAN PENGIKAT TERHADAP SIFAT FISIK TABLET PARASETAMOL SECARA GRANULASI BASAH
}

\author{
Sapri, Dedi Setiawan, Rizki Khairunnisa \\ Akademi Farmasi Samarinda \\ e-mail : sapri_juli86@yahoo.co.id
}

\begin{abstract}
The research about influent the use of cempedak seed starch (Arthocarpus champeden Lour) as a binder to the physical properties of paracetamol tablet in wet granulation has been conducted. Cempedak seed starch can improve the quality of materials, increase the viscosity, gelation ability, rehydration ability and increase the solubility. Paracetamol tablet be made in three formulas, with various concentration binders formula FA 6\%, FB 8\% and FC 10\%. The resulting granules and tablets were evaluated. Granule evaluation includes fluiditas test and moisture content. Tablet evaluation includes uniformity of weight test, uniformity of size, hardness test and disintegration test. Granule evaluation results show that all formulas has qualified, except granule formula FA wich contain moisture $1.78 \%$. Tablet evaluation results show that all formulas has qualified FI Ed. IV. Whereas for hardness test, tablet formula FA not eligible because it has hardness $3.8 \mathrm{Kg} / \mathrm{cm}^{2}$. The results of this research indicate that cempedak seed starch can be used as a binder in the manufacture of wet granulation paracetamol tablets. The higher the concentration used cempedak seed starch, than produced a good tablet. Cempedak seed starch can be used as a binder in concentration $8 \%$ and $10 \%$.
\end{abstract}

Key Words : Cempedak seed starch (Arthocarpus champeden Lour.), paracetamol tablet, wet granulation

\begin{abstract}
ABSTRAK
Telah dilakukan penelitian tentang pengaruh penggunaan pati biji cempedak (Arthocarpus champeden Lour.) sebagai bahan pengikat terhadap sifat fisik tablet parasetamol secara granulasi basah. Pati biji cempedak dapat meningkatkan kualitas bahan, berupa naiknya viskositas, kemampuan gelasi, daya rehidrasi dan kemudahan melarut. Tablet parasetamol dibuat tiga formula dengan variasi konsentrasi bahan pengikat formula FA 6\%, FB 8\% dan FC $10 \%$. Granul dan tablet yang dihasilkan dievaluasi, evaluasi granul meliputi waktu alir granul dan kandungan lembab, evaluasi tablet yang meliputi uji keseragaman bobot, keseragaman ukuran, kekerasan dan waktu hancur. Hasil evaluasi granul menunjukkan bahwa granul yang dihasilkan dari ketiga formula telah memenuhi persyaratan, kecuali granul formula FA yang memiliki kandungan lembab $1,78 \%$. Hasil evaluasi tablet menunjukkan bahwa tablet dari ketiga formula tersebut telah memenuhi persyaratan tablet pada FI Ed. IV. Sedangkan untuk uji kekerasan, tablet formula FA tidak memenuhi persyaratan karena memiliki kekerasan 3,8 $\mathrm{Kg} / \mathrm{cm}^{2}$. Hasil penelitian ini menunjukkan bahwa pati biji cempedak dapat digunakan sebagai bahan pengikat dalam pembuatan tablet parasetamol secara granulasi basah. Semakin tinggi konsentrasi pati biji cempedak yang digunakan, maka sifat fisik tablet yang dihasilkan semakin baik. Pati biji cempedak dapat digunakan sebagai bahan pengikat tablet dan memberikan sifat fisik tablet yang baik pada konsentrasi $8 \%$ dan $10 \%$.
\end{abstract}

Kata Kunci: Pati biji cempedak (Arthocarpus champeden Lour.), tablet parasetamol, granulasi basah 


\section{PENDAHULUAN}

Tablet merupakan bentuk sediaan yang paling banyak digunakan. Hal ini disebabkan tablet memiliki kelebihan yang tidak dimiliki oleh sediaan farmasi yang lain, baik dari segi produksi, penyimpanan, distribusi maupun pemakaiannya. Berdasarkan hal-hal tersebut maka pembuatan tablet dan upaya untuk lebih mengembangkan teknologi tabletasi terus dilakukan.

Tablet dibuat dari bahan aktif dan bahan tambahan yang meliputi bahan pengisi, penghancur, pengikat dan pelicin. Metode pembuatannya bisa dilakukan dengan granulasi basah, granulasi kering atau kempa langsung. Tablet yang baik harus memenuhi persyaratan yang cukup, antara lain: cukup kuat untuk mempertahankan bentuknya mulai produksi sampai digunakan oleh pasien, mempunyai kandungan bahan obat dan bobot tablet yang seragam, warna yang menarik, ukuran dan bentuk yang pantas serta terjamin stabilitasnya (1).

Semua bahan tambahan (eksipien) tablet harus memenuhi kriteria tertentu dalam formulasi, seperti; tidak toksik, inert secara fisiologis dan terhadap zat aktif, bebas dari kandungan mikroba, kompatibel dengan zat warna, stabil secara fisik dan kimia baik secara tunggal dan/atau dalam kombinasi dengan zat aktif dan komponen tablet lainnya (2).

Eksipien yang sudah ada sekarang sudah dievaluasi berulang kali selama 50 tahun dan masih digunakan zat yang sama hingga dewasa ini. Oleh karena itu, formulator tidak boleh segan mengubah eksipien lama atau mengevaluasi eksipien baru (1). Kajian ulang pustaka yang dilakukan oleh formulator menunjukan bahwa jumlah total eksipien mutakhir yang digunakan secara signifikan kurang dari 25. Bahan tersebut memenuhi kebutuhan 6 kategori utama sebagai eksipien, yakni pengisi, pengikat, lubrikan, zat pewarna dan perasa (2).

Salah satu fungsi penting eksipien dalam formulasi tablet adalah membentuk aglomerat dari bahan aktif, pengisi, dan eksipien lain, dengan pengecualian lubrikan, glidant, dan lain sebagainya. Hal ini dicapai dengan menggunakan eksipien yang mempunyai sifat mengikat karena forsa kohesi dan adhesi (3). Ada dua golongan bahan pengikat yang sering digunakan dalam formulasi tablet, yaitu bahan gula dan bahan polimerik. Bahan polimerik terdiri dari dua kelas yaitu polimer alam dan polimer sintetis (2).

Eksipien polimer alam yang sering digunakan sebagai bahan pengikat dalam pembuatan tablet adalah pati. Banyak penelitian melaporkan bahwa jenis pati dari berbagai tanaman dapat dimanfaatkan sebagai substitusi bahan-bahan pembantu yang telah dikenal dalam formulasi tablet. Pati yang umumnya digunakan adalah pati singkong, jagung, gandum, kentang dan beras (4). Pencarian bahan-bahan baru yang dapat digunakan sebagai bahan pengikat untuk granulasi basah telah dimulai antara lain penggunaan pati biji durian (Durio zibethinus Murr.) (5), dan pati biji Nangka (Arthocarpus heterophyllus Lamk.) (6).

Tanaman lain yang menghasilkan pati adalah cempedak (Arthocarpus champeden Lour) yang menghasilkan pati dari bijinya. Rata-rata tiap buah cempedak berisi biji yang beratnya sepertiga bagian berat dari seluruh buah, sisanya adalah kulit dan daging buah. Cempedak merupakan salah satu tanaman tropis yang terdapat di Indonesia (7), sehingga potensi tersedianya pati cempedak ini cukup besar. Pati biji cempedak dapat meningkatkan kualitas 
bahan, karena menyebabkan perubahan karakteristik yang lebih baik dari tepung yang dihasilkan berupa naiknya viskositas, kemampuan gelasi, daya rehidrasi dan kemudahan melarut (8).

Pada penelitian ini pati biji cempedak yang digunakan diharapkan memiliki kemampuan sebagai bahan pengikat dalam pembuatan tablet dengan metode granulasi basah. Akan diselidiki sampai sejauh mana pengaruh penggunaan pati biji cempedak pada berbagai tahap pembuatan tablet dan pengaruhnya terhadap sifat fisik tablet. Selain itu ingin diketahui konsentrasi optimum dari pati biji cempedak yang memenuhi persyaratan sebagai bahan pengikat tablet.

Berdasarkan latar belakang di atas, maka dilakukan penelitian mengenai pengaruh pati biji cempedak (Arthocarpus champeden Lour) sebagai bahan pengikat terhadap sifat fisik tablet Parasetamol yang dibuat secara granulasi basah.

\section{METODE}

Penelitian yang dilakukan adalah penelitian eksperimental. Penelitian eksperimental adalah percobaan yang bertujuan untuk mengetahui suatu gejala atau pengaruh yang timbul akibat dari adanya perlakuan tertentu. Rancangan percobaan yang digunakan dalam penelitian ini adalah Rancangan Acak Lengkap (RAL) dengan tiga taraf perlakuan formula bahan. Penelitian yang dilakukan mengenai pengaruh penggunaan pati biji cempedak (Arthocarpus champeden Lour) sebagai bahan pengikat terhadap sifat fisik tablet Parasetamol. Tahap penelitian ini dimulai dengan pengumpulan dan pengolahan biji cempedak, pemeriksaan pati biji cempedak, formulasi tablet parasetamol dengan metode granulasi basah, evaluasi granul dan uji sifat fisik tablet. Penelitian ini dilaksanakan selama dua bulan di Laboratorium Terpadu I Akademi Farmasi Samarinda.

\section{Bahan}

Bahan-bahan yang digunakan antara lain adalah amilum, aquadest, biji cempedak, laktosa, larutan $\mathrm{I}_{2} 0,005 \mathrm{M}, \mathrm{Mg}$. stearat, $\mathrm{NaOH} 0,1 \mathrm{~N}$, parasetamol dan talkum.

\section{Alat \\ Alat-alat yang digunakan antara lain adalah, alat pengukur kekerasan tablet (Hardness tester) (Monsanto ${ }^{\circledR}$ ). alat uji waktu hancur (Desintegration tester), ayakan dengan no. mesh 14, 16, 40 dan 80, blender $\left(\right.$ National $\left.^{\circledR}\right)$, corong uji sifat alir, jangka sorong, mesin pencetak tablet Single punch, oven (Memmert ${ }^{\circledR}$ ), perangkat gelas dan timbangan elektrik/digital Ohauss (Adventurer ${ }^{\mathrm{TM}}$ ). \\ Pengumpulan dan Pengolahan Biji Cempedak}

Cempedak dibeli dari pedagang di Pasar Merdeka Samarinda. Lalu diambil biji cempedak dan dicuci bersih. Biji cempedak dibuang kulitnya, dicuci dengan air mengalir, dipotong kecil-kecil dan diblender dengan penambahan air. Bahan disaring dengan kain putih, diperas, ampas diblender kembali dengan penambahan air, disaring dan diperas kembali. Filtrat diendapkan sampai airnya jernih dan buang airnya. Pati dicuci kembali sampai bersih kemudian keringkan dalam oven. Pati yang telah kering digiling dan ayak melalui mesh 80.

Pemeriksaan pati biji cempedak dilakukan menurut pemeriksaan pati singkong yang terdapat pada FI edisi IV (9), meliputi:

a. Pemerian: bentuk, warna, rasa dan bau. 
Pengaruh Penggunaan Pati Biji Cempedak (Arthocarpus Champeden Lour) Sebagai Bahan Pengikat Terhadap Sifat Fisik Tablet Parasetamol Secara Granulasi Basah

b. Kelarutan: dalam air dingin dan dalam etanol.

ml larutan dengan $0,05 \mathrm{ml}$ iodium $0,005 \mathrm{M}$.

c. Identifikasi: Panaskan sampai mendidih selama 1 menit suspensi $1 \mathrm{~g}$ dalam $50 \mathrm{ml}$ air, dinginkan, campur 1

d. Keasaman: diperlukan tidak lebih $2 \mathrm{ml}$ $\mathrm{NaOH} 0,1 \mathrm{~N}$

Formulasi Tablet Parasetamol dengan Metode Granulasi Basah

Tabel 1. Formulasi tablet Parasetamol dengan metode granulasi basah

\begin{tabular}{|c|c|c|c|c|}
\hline \multirow{2}{*}{ No. } & \multirow{2}{*}{ Bahan } & \multicolumn{3}{|c|}{ Formula } \\
\hline & & FA & FB & $\mathrm{FC}$ \\
\hline & Fase dalam & & & \\
\hline 1 & Parasetamol (mg) & 250 & 250 & 250 \\
\hline 2 & Amilum (penghancur) $(\%)$ & 10 & 10 & 10 \\
\hline 3 & Laktosa (pengisi) $(\%)$ & q.s. & q.s. & q.s. \\
\hline 4 & $\begin{array}{l}\text { Mucilago pati cempedak } \\
\text { (pengikat) }(\%)\end{array}$ & 6 & 8 & 10 \\
\hline & Fase luar & & & \\
\hline 5 & Amilum (penghancur) $(\%)$ & 5 & 5 & 5 \\
\hline 6 & Mg stearat $(\%)$ & 2 & 2 & 2 \\
\hline 7 & Talkum $(\%)$ & 3 & 3 & 3 \\
\hline & Berat tablet (mg) & 350 & 350 & 350 \\
\hline
\end{tabular}

\section{Cara Kerja:}

a. Ditimbang semua bahan sesuai dengan formula.

b. Dibuat mucilago pati biji cempedak dengan menambahkan air panas (sesuai dengan persentase $\mathrm{b} / \mathrm{v}$ ), aduk hingga bening / jernih di atas water bath.

c. Parasetamol ditambahkan amilum dan laktosa, aduk homogen.

d. Kemudian ditambahkan larutan pengikat sedikit demi sedikit, aduk hingga menjadi massa yang dapat dikepal.

e. Hasil pencampuran awal diayak dengan ayakan mesh no. 14, keringkan didalam oven suhu $60^{\circ} \mathrm{C}$ hingga kadar air 2-4\% selama 60 menit.

f. Diayak granul kering dengan ayakan mesh no. 16, kemudian ditambahkan amilum, talkum dan magnesium stearat melalui ayakan mesh no. 40, aduk homogen 5 menit. g. Dilakukan evaluasi terhadap granul, meliputi uji kadar lembab dan sifat alir granul.

h. Dicetak dengan mesin tablet singgle punch dengan bobot rata-rata tablet $350 \mathrm{mg}$.

i. Dilakukan evaluasi terhadap tablet, meliputi uji kekerasan, waktu hancur, keseragaman ukuran (ketebalan dan diameter) dan keseragaman bobot.

\section{Evaluasi Granul}

a. Kadar Lembab

Ditimbang seksama 5,0 g granul, panaskan dalam lemari pengering sampai bobot konstan $\left(105^{\circ} \mathrm{C}\right)$ selama 2 jam.

Perhitungan $: \% M C=\frac{w_{0}-W_{1}^{1}}{w 0} \times 100 \%$

$\mathrm{MC}=$ Moisture Content, kandungan lembab

$\mathrm{W}_{0}=$ Bobot granul awal

$\mathrm{W}_{1}=$ Bobot granul setelah pengeringan

Persyaratan $=2-4 \%$ 


\section{b. Sifat Alir}

Ditimbang 25,0 g granul, tempatkan pada corong alat uji waktu alir dalam keadaan tertutup. Buka penutupnya biarkan granul mengalir, catat waktunya, lakukan 3 kali.

Persyaratan : $100 \mathrm{~g}$ granul waktu alirnya tidak lebih dari 10 detik.

\section{Uji Sifat Fisik Tablet}

\section{a. Keseragaman Bobot}

Ditimbang 20 tablet, dihitung bobot ratarata tiap tablet. Jika dihitung satu persatu, tidak boleh lebih dari 2 tablet yang menyimpang dari bobot rata-rata lebih besar dari harga yang ditetapkan kolom $\mathrm{A}$ dan tidak boleh 1 tablet pun yang bobotnya menyimpang dari bobot rata-rata lebih dari harga dalam kolom $\mathrm{B}$. jika perlu dapat digunakan 10 tablet dan tidak 1 tablet yang bobotnya menyimpang dari bobot rata-rata yang ditetapkan dalam kolom A dan B.

\section{b. Keseragaman Ukuran}

Diambil 20 tablet, ukur diameter dan ketebalannya menggunakan jangka sorong. Hitung rata-rata dan SD nya.

Persyaratan: kecuali dinyatakan lain, diameter tidak lebih dari 3 kali dan tidak kurang dari $3 / 4$ kali tebal tablet. Tebal tablet pada umumnya tidak lebih besar dari $50 \%$ diameter.

\section{c. Kekerasan}

Diambil 20 tablet, ukur kekerasan menggunakan alat ukur kekerasan. Hitung rata-rata dan SD nya.

Persyaratan: Ukuran yang didapat per tablet minimal $4 \mathrm{~kg} / \mathrm{cm}^{2}$, maksimal 10 $\mathrm{kg} / \mathrm{cm}^{2}$.

\section{d. Waktu Hancur}

Dimasukkan masing-masing 1 tablet ke dalam tabung dari alat uji waktu hancur, masukkan 1 cakram pada tiap tabung dan jalankan alat. Gunakan air sebagai media dengan suhu $37 \pm 2^{\circ} \mathrm{C}$. semua tablet harus hancur sempurna. Bila 1 atau 2 tablet tidak hancur sempurna, ulangi pengujian dengan 12 tablet lainnya.

\section{Analisis Data}

Data yang dikumpulkan adalah data kuantitatif, yaitu berupa data hasil uji keseragaman bobot, keseragaman ukuran (diameter dan ketebalan), kekerasan tablet dan waktu hancur. Kemudian disesuaikan dengan persyaratan tablet yang terdapat dalam Farmakope Indonesia edisi IV.

Data sifat fisik tablet parasetamol yang diperoleh dianalisis dengan analisis statistik deskriptif dan inferensial/induktif. Statistika inferensial yang digunakan adalah analisis variansi (ANAVA/ANOVA) dengan tingkat kebermaknaan $5 \%(\alpha=0,05)$. Jika hasil uji ANAVA berbeda nyata $(\mathrm{P}<0,05)$ terhadap sifat fisik yang diukur, maka akan dilanjutkan dengan analisis Least Significant Difference (LSD) untuk mengetahui lebih lanjut kelompok mana saja yang berbeda nyata.

\section{HASIL DAN PEMBAHASAN}

\section{A. Pembuatan Pati Biji Cempedak}

Pati diambil dari biji buah cempedak (Artocarpus champeden Lour.) yang sudah masak dengan ciri-ciri antara lain: tangkai buah sudah menguning, bau yang kuat dan spesifik yang mudah tercium, warna buah hijau kekuningan. Dari 500 g biji basah didapatkan pati yang berupa serbuk 
Pengaruh Penggunaan Pati Biji Cempedak (Arthocarpus Champeden Lour) Sebagai Bahan Pengikat Terhadap Sifat Fisik Tablet Parasetamol Secara Granulasi Basah

berwarna putih kekuningan dengan Pemeriksaan pati biji cempedak dilakukan rendemen sebesar $16,5 \%$. sesuai dengan pemeriksaan pati singkong menurut FI Ed. IV yang tercantum pada Tabel 2

Persyaratan:

\begin{tabular}{lll} 
& \multicolumn{2}{l}{ Penyimpangan bobot rata-rata $(\%)$} \\
Bobot rata-rata & A & B \\
$25 \mathrm{mg}$ atau kurang & 15 & 30 \\
$26 \mathrm{mg}-150 \mathrm{mg}$ & 10 & 20 \\
$151 \mathrm{mg}-300 \mathrm{mg}$ & 7,5 & 15 \\
Lebih dari $300 \mathrm{mg}$ & 5 & 10
\end{tabular}

Tabel 2. Data Hasil Pemeriksaan Pati Biji Cempedak

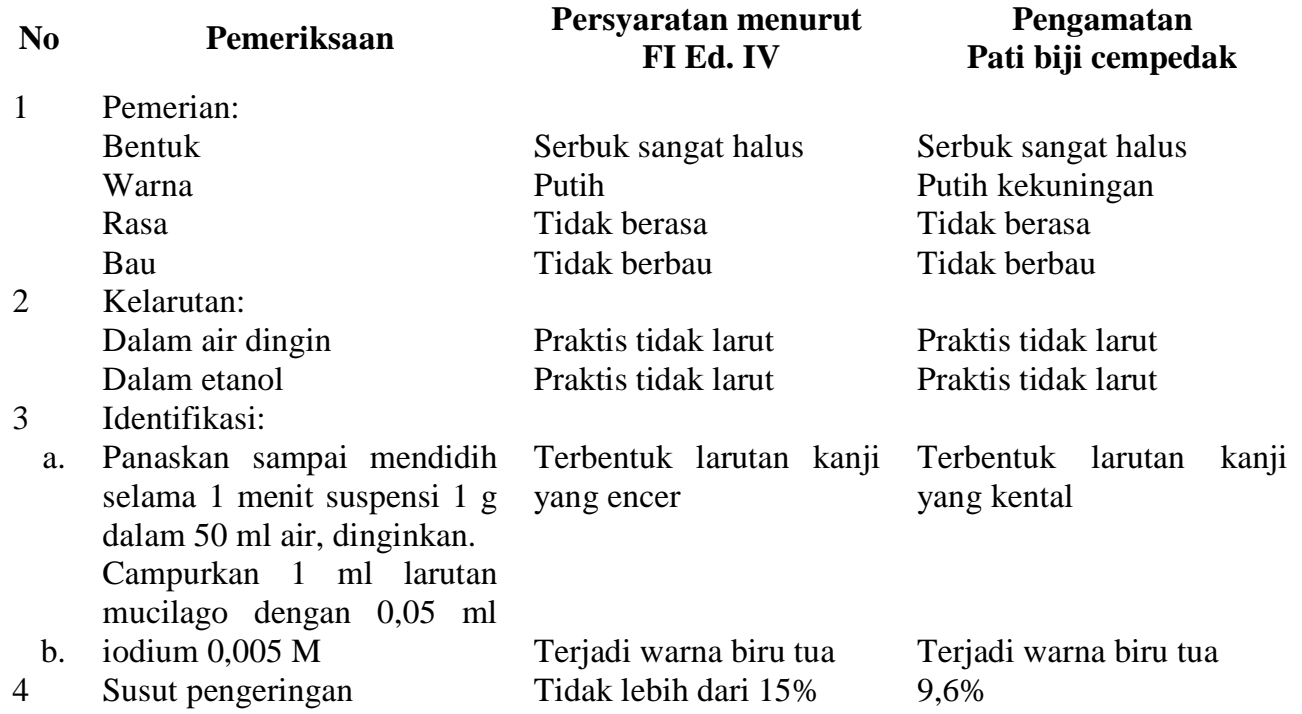

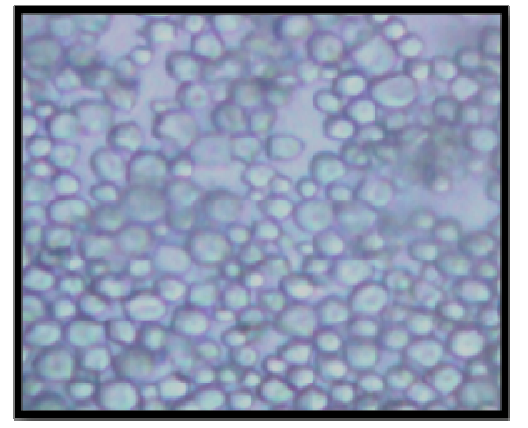

Gambar 1. Hasil Uji Mikroskopik Pati Biji Cempedak Dengan Perbesaran 12,5 x 40 
Pati biji cempedak yang didapat berwarna putih kekuningan, hal ini dipengaruhi oleh warna dari bahan yang akan dibuat pati, dalam hal ini adalah kotiledon dari biji cempedak yang berwarna putih kekuningan dan dipengaruhi oleh kandungan getah yang terkandung dalam biji cempedak. Selain itu kualitas air yang digunakan pada proses pembuatan pati juga menentukan warna pati. Berdasarkan hasil uji mikroskopik pati biji cempedak terlihat bentuk partikel pati biji cempedak serupa dengan bentuk pati pada umumnya yaitu ada yang berbentuk granul bulat dan ada pula yang bagian ujung membulat seperti topi baja yang dapat dilihat pada Gambar 1.Pati biji cempedak praktis tidak larut dalam air dingin dan dalam alkohol. Pati biji cempedak membentuk mucilago yang kental jika dipanaskan dalam air, hal ini disebabkan karena kandungan amilosa dan amilopektin yang terkandung dalam pati biji cempedak. Amilosa dapat mempengaruhi proses pengembangan pati dan tingkat kekentalan mucilago. Amilosa berperan dalam pembentukan gel sedangkan amilopektin membentuk sifat viskoelastisitas (5). Mucilago pati biji cempedak ketika ditetesi larutan iodium menghasilkan warna biru tua. Pewarnaan biru amilum-iod disebabkan oleh terbentuknya suatu senyawa dalam dari amilosa-amilum dari atom iod. Fraksi amilosa-amilum mempunyai bentuk helikal dan membentuk celah berbentuk saluran. Warna biru disebabkan oleh ketujuh elektron luar atom iod yang mudah bergerak.Susut pengeringan pati biji cempedak sebesar $9,6 \%$ hal ini telah memenuhi persyaratan pati pada FI Ed. IV yaitu tidak lebih dari $15 \%$.

\section{B. Hasil Evaluasi Granul}

Sebelum massa granul dicetak menjadi tablet umumnya harus melalui serangkaian evaluasi. Hal ini penting dilakukan untuk mengetahui kelayakan pencetakan suatu tablet. Berikut tabel hasil evaluasi granul dari berbagai formula yang dibuat.

Berdasarkan hasil yang didapat menunjukan bahwa waktu alir granul dengan bahan pengikat pati biji cempedak dari formula FA, FB dan FC terjadi penurunan, yaitu 2,2 detik, 1,9 detik dan 1,5 detik. Walaupun terjadi variasi waktu alir dari formula tersebut tetapi masih tetap berada dalam batas persyaratan. Granul dalam bentuk yang hampir bulat dan permukaan halus akan lebih mudah untuk mengalir.

Makin besar konsentrasi pati biji cempedak, maka makin cepat waktu alirnya. Hal ini disebabkan karena semakin tinggi konsentrasi pengikat maka massa granul yang dihasilkan semakin baik, yaitu memberikan bentuk granul yang bulat atau tidak beraturan (hampir bulat) dengan permukaan yang halus sehingga mudah untuk mengalir. Peranan pengikat adalah untuk memberikan kohesivitas yang diperlukan untuk mengikat partikel-partikel padat, semakin besar konsentrasi pengikat, maka dapat meningkatkan pembesaran ukuran untuk membentuk granul sehingga dapat memperbaiki sifat aliran campuran selama proses pembuatan. Selain itu, meningkatnya konsentrasi bahan pengikat juga mengakibatkan kekuatan granul dan kekuatan tablet meningkat.

Penetapan kandungan lembab granul kering sangatlah penting. Kandungan lembab yang tinggi dapat menyebabkan tablet sumbing atau melekat pada permukaan punch tablet dan stabilitas kimia buruk akibat terjadi hidrolisis, bahkan jika terlalu lembab maka granul akan ditumbuhi mikroba dan jamur. Granul yang lewat kering dapat mengakibatkan kekerasan dan friabilitas tablet yang buruk. Persyaratan kandungan lembab granul 
Pengaruh Penggunaan Pati Biji Cempedak (Arthocarpus Champeden Lour) Sebagai Bahan Pengikat Terhadap Sifat Fisik Tablet Parasetamol Secara Granulasi Basah

dalam pembuatan tablet secara granulasi basah adalah sebesar 2-4\%. Hasil uji kandungan lembab untuk formula FA sebesar $1,78 \%$, FB sebesar $2,03 \%$ dan FC sebesar 2,61\%. Granul kering formula FA memiliki kandungan lembab yang rendah sehingga granul yang dihasilkan friabilitasnya buruk. Ketika diekstrusikan melalui ayakan mesh 20, maka

Tabel 3. Data Hasil Evaluasi Granul

$\begin{array}{cc}\text { Formula } & \text { Waktu Alir (detik) } \\ \text { FA } & 2,2 \\ \text { FB } & 1,9 \\ \text { FC } & 1.5 \\ \text { Persyaratan } & 100 \text { g granul }<10 \\ & 25 \text { g granul }<2,5\end{array}$

menghasilkan banyak fines. Granul kering formula FB dan FC menghasilkan granul yang cukup baik. Granul yang dihasilkan cukup kuat, tidak rapuh dan ketika diekstruksikan melalui ayakan mesh 20 fines yang dihasilkan sedikit, sehingga dapat diketahui bahwa formula FB dan FC menghasilkan granul yang baik.

Tabel 4. Data Hasil Evaluasi Tablet

$\begin{array}{lc}\text { Formula } & \begin{array}{c}\text { Keseragaman } \\ \text { bobot }\end{array} \\ \text { FA } & \text { A1 }=4,99 \% \\ & \text { A2 }=4,29 \% \\ \text { B }=4,99 \% \\ \text { FB } & \text { A }=4,33 \% \\ & \text { A2 }=3,98 \% \\ & \mathrm{~B}=4,33 \% \\ \text { FC } & \text { A1 }=3,94 \% \\ & \mathrm{~A} 2=3,74 \% \\ \text { Persyaratan } & \text { A }=7,5 \% \text { B }=15 \% \\ \text { Keterangan } & \text { Memenuhi Syarat }\end{array}$

$\begin{array}{cccc}\begin{array}{c}\text { Keseragaman ukuran } \\ \text { Diameter }(\mathbf{m m})\end{array} & \begin{array}{c}\text { Kebal }(\mathbf{m m}) \\ \mathbf{\text { Kekerasan }} \\ \left(\mathbf{k g} \mathbf{c m}^{\mathbf{2}}\right)\end{array} & \begin{array}{c}\text { Waktu } \\ \text { hancur }\end{array} \\ 8 & 5 & 3,8 & \begin{array}{c}1 \text { menit } 40 \\ \text { detik }\end{array} \\ 8 & 5 & 4,3 & \begin{array}{c}3 \text { menit } 13 \\ \text { detik }\end{array} \\ 4 / 3 x t e b a l \leq D \leq 3 x t e b a l & 5,6 & \begin{array}{c}4 \text { menit } 27 \\ \text { detik }\end{array} \\ \text { Memenuhi Syarat } & \begin{array}{c}4-8 \\ \text { Memenuhi } \\ \text { Syarat }\end{array} & \begin{array}{c}\text { Memenuhi } \\ \text { Syarat }\end{array}\end{array}$

\section{Hasil Evaluasi Tablet}

Untuk menjamin keseragaman, bukan hanya penampilannya saja tetapi juga keseragaman kualitasnya, maka perlu dilakukan evaluasi sifat fisik tablet, yaitu uji keseragaman bobot, uji keseragaman ukuran, uji kekerasan dan uji waktu hancur tablet, karena sifat fisik dari tablet sangat mempengaruhi biofarmasetika dan bioavailabilitas dari sistem tablet.

Hasil evaluasi sifat fisik tablet yang meliputi keseragaman bobot, ukuran dan waktu hancur tablet dapat dilihat pada Tabel 4, hasil yang diperoleh mengikuti persyaratan yang ditetapkan dalam FI Ed. IV, sedangkan untuk uji kekerasan memang tidak dicantumkan dalam FI Ed. IV, tetapi kekerasan ini penting karena harus dapat menjamin keutuhan tablet selama penanganan sampai ke konsumen. Hasil yang diperoleh untuk uji kekerasan tablet mengikuti persyaratan yang terdapat pada Pharmaceutical Technology Fundamental Pharmaceutics.

\section{Keseragaman bobot tablet}

Pada tablet yang didesain mengandung sejumlah obat di dalam formula, berat tablet yang dibuat harus diuji 
keseragamnya, tujuannya selain untuk mendapatkan keseragaman bobot yang baik, uji keseragaman bobot juga dapat menentukan keseragaman isi/kandungan bahan obat dalam tablet dan memastikan bahwa setiap tablet mengandung jumlah obat yang tepat. Tablet harus memiliki keseragaman bobot yang baik yaitu dengan memiliki standar deviasi yang ditetapkan dalam FI Ed. IV, selain itu syarat lain yang harus dipenuhi agar tablet dikatakan seragam adalah mempunyai koefisien variasi kurang dari 5\% (1). Tablet dengan kandungan zat aktif 100-200 mg maka bobot yang dapat dibuat adalah 150-300 $\mathrm{mg}(1)$.

Tablet parasetamol formula FA memiliki bobot rata-rata $284,2 \mathrm{mg}$, formula $\mathrm{FB}$ $288,5 \mathrm{mg}$, dan formula FC 299,8 mg. Hasil uji keseragaman bobot tablet parasetamol formula FA, FB dan FC memenuhi persyaratan yang terdapat pada FI Ed. IV, yaitu tidak boleh lebih dari 2 tablet yang masing-masing bobotnya menyimpang dari bobot rata-ratanya lebih besar dari 7,5\% dan tidak boleh satu tablet pun yang bobotnya menyimpang dari bobot rataratanya lebih dari $15 \%$.

\section{Keseragaman ukuran tablet}

Ketebalan yang diinginkan dalam tablet harus diperhitungkan terhadap volume dari bahan yang diisikan ke dalam cetakan, diameter cetakan dan besarnya tekanan untuk menekan bahan isian. Untuk mendapatkan tablet yang seragam diameter dan tebalnya harus dilakukan pengawasan, yaitu dengan melakukan pengukuran sampel supaya meyakinkan bahwa diameter dan ketebalannya sudah sesuai.

Tablet harus memiliki keseragaman ukuran yang baik yaitu dengan memenuhi persyaratan tablet pada FI Ed. IV, selain itu juga harus memenuhi persyaratan umum tablet oral yang biasanya berdiameter $3 / 16$ - $1 / 2$ inci (1) dan juga memenuhi persyaratan tablet pada umumnya yang biasanya berukuran 5-17 mm. Tujuan dari uji keseragaman ukuran adalah untuk memastikan jumlah bahan obat yang diisikan ke dalam cetakan dan tekanan yang digunakan waktu proses kompresi seragam.

Tablet parasetamol formula FA, FB dan FC memiliki ukuran yang sama, yaitu diameter $8 \mathrm{~mm}$ dan tebal $5 \mathrm{~mm}$. Hasil uji keseragaman ukuran tablet parasetamol formula FA, FB dan FC memenuhi persyaratan keseragaman ukuran menurut FI Ed. IV, yaitu keseragaman ukuran tablet, kecuali dinyatakan lain, diameter tablet tidak lebih dari 3 kali dan tidak kurang dari 1 1/3 kali tebal tablet.

\section{Uji kekerasan tablet}

Uji kekerasan tablet dilakukan untuk mengetahui kekerasan tablet. Tablet harus mempunyai kekuatan atau kekerasan tertentu serta tahan atas kerenyahan agar dapat bertahan terhadap berbagai guncangan mekanik pada saat pembuatan, pengepakan, dan pengapalan. Selain itu tablet juga harus dapat bertahan terhadap perlakuan berlebihan oleh konsumen. Kekerasan tablet yang cukup serta tahan penyerbukan dan kerenyahan merupakan persyaratan penting bagi penerimaan konsumen (1).

Kekerasan dinyatakan dalam satuan kg dari tenaga yang dibutuhkan untuk memecah tablet. Kekerasan untuk tablet secara umum yaitu $4-8 \mathrm{~kg}$.

Kekerasan tablet dipengaruhi oleh perbedaan massa granul yang mengisi die pada saat pencetakan tablet dan tekanan kompresi. Komposisi, homogenitas campuran bahan-bahan yang akan dicetak, 
kecepatan aliran massa ke dalam mesin cetak serta perubahan tekanan pencetakan mempengaruhi kekerasan tablet yang dihasilkan. Selain itu, berbedanya nilai kekerasan juga dapat diakibatkan oleh variasi jenis dan jumlah bahan tambahan yang digunakan pada formulasi. Bahan pengikat adalah contoh bahan tambahan yang bisa menyebabkan meningkatnya kekerasan tablet bila digunakan terlalu pekat (1). Tablet parasetamol formula FA memiliki kekerasan $3,8 \mathrm{Kg} / \mathrm{cm}^{2}$, formula FB $4,3 \mathrm{Kg} / \mathrm{cm}^{2}$, formula FC $5,6 \mathrm{Kg} / \mathrm{cm}^{2}$. Hasil uji kekerasan tablet menunjukkan bahwa tablet formula FA tidak memenuhi persyaratan, karena memiliki kekerasan kurang dari persyaratan kekerasan tablet, yaitu $4-8 \mathrm{Kg} / \mathrm{cm}^{2}$.

\section{Uji waktu hancur tablet}

Tablet umumnya diformulasi dengan suatu disintegran yang akan menyebabkan tablet pecah dan hancur dalam air dan cairan lambung. Faktor-faktor yang mempengaruhi disintegrasi tablet antara lain sifat fisik dan kimia granul, kekerasan, porositas dan bahan disintegran yang digunakan.

Uji waktu hancur tidak menyatakan secara langsung bahwa tablet atau bahkan zat aktif terlarut sempurna. Berdasarkan hasil penelitian uji waktu hancur dapat ditetapkan bahwa hubungan antara disintegrasi dan kelarutan (disolusi) tidak seharusnya diterima begitu saja. Akan tetapi karena kelarutan obat dari pecahanpecahan (partikel atau granul) tablet tampaknya mengontrol sebagian atau seluruh obat yang ada di dalam darah, disintegrasi tetap dipakai sebagai petunjuk dalam pembuatan formula optimum tablet, serta sebagai uji control dalam proses untuk menjamin keseragaman antar tablet (1)
Waktu hancur tablet parasetamol formula FA, FB dan FC berbeda. Formula FA memiliki waktu hancur 1 menit 40 detik, formula FB 3 menit 13 detik dan formula FC 4 menit 27 detik. Berdasarkan hasil uji waktu hancur tersebut, maka dapat diketahui bahwa ketiga formula tablet tersebut telah memenuhi persyaratan waktu hancur pada FI Ed. IV, yaitu waktu hancur untuk tablet tidak bersalut tidak lebih dari 15 menit.

\section{Analisis Data}

Data sifat fisik tablet parasetamol yang diperoleh dianalisis dengan analisis statistika deskriptif dan inferensial/induktif. Statistik deskriptif merupakan kegiatan mulai dari pengumpulan data sampai mendapatkan informasi dengan jalan menyajikan dan menganalisis data yang telah dikumpulkan untuk menggambarkan karakteristik sifat fisik tablet.

Data hasil evaluasi tablet yang diperoleh terlebih dahulu diuji normalitasnya dengan uji Kolmogorov-Smirnov untuk mengetahui apakah data telah terdistribusi normal atau tidak dan uji homogenitas varian apakah varian homogen atau tidak. Bila data terdistribusi normal dan homogen, maka dilanjutkan dengan uji statistik parametrik analisis varian (ANAVA) satu jalan dengan menggunakan Statistical Process and Service Solution (SPSS) for window versi 16.0 dengan taraf kepercayaan $95 \%$ untuk mengetahui apakah data tersebut memiliki perbedaan bermakna antar formula tablet. Setelah uji ANAVA satu jalan dilanjutkan uji LSD untuk mengetahui perbedaan antara formula tablet. Hasil uji ANAVA satu jalan akan menunjukkan perbedaan yang bermakna jika $\mathrm{p}<0,05$ dan berbeda tidak bermakna jika $p>0,05$. 

Sifat Fisik Tablet Parasetamol Secara Granulasi Basah

\section{Keseragaman bobot tablet}

Data hasil uji keseragaman bobot yang diperoleh terlebih dahulu diuji normalitasnya dengan uji KolmogorovSmirnov untuk mengetahui distribusi data dan uji homogenitas varian. Hasil uji memperlihatkan data terdistribusi normal dengan nilai sebesar $0,560(0,560>0,05)$. Hasil uji homogenitas varian diperoleh hasil signifikan 0,561 yang berarti varian homogen $(0,561>0,05)$.

Tabel 5. Hasil Uji LSD Keseragaman Bobot Tablet
Hasil uji ANAVA satu jalan diperoleh hasil yang signifikan. Hal ini ditunjukkan dengan nilai signifikan 0,000 yang berarti lebih kecil dari 0,05 , sehingga bisa disimpulkan bahwa keseragaman bobot tiap formula memang terdapat perbedaan yang bermakna. Kemudian dilanjutkan dengan uji LSD, hasil uji LSD keseragaman bobot antar formula dapat dilihat pada Tabel 5.

\section{FA}

P (signifikansi)

FA
FB
FC

Keterangan:

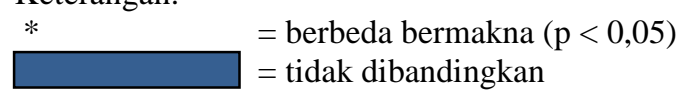

Hasil uji LSD keseragaman bobot antar formula tablet menunjukkan bahwa terdapat perbedaan bermakna antara formula FA dengan formula FB karena memiliki nilai signifikan 0,049 $(0,049<0,05)$, formula FA dengan formula FC terdapat perbedaan yang bermakna karena memiliki nilai signifikan 0,000 $(0,000<0,05)$ dan formula FB dengan formula FC terdapat perbedaan yang bermakna karena memiliki nilai signifikan $0,000(0,000<0,05)$. Terjadinya perbedaan yang bermakna ini dikarenakan masingmasing formula memiliki \% penyimpangan yang berbeda. Dilihat dari \% penyimpangannya, maka tablet parasetamol dengan formula $\mathrm{FC}$ memiliki $\%$ penyimpangan yang terkecil yaitu $\mathrm{A} 1=$ $3,94 \%, \mathrm{~A} 2=3,74 \%$, formula $\mathrm{FB}$ yaitu $\mathrm{A} 1=$ $4,33 \%, A 2=3,98 \%$ sedangkan FA yaitu $\mathrm{A} 1=4,99 \%, \mathrm{~A} 2=4,29 \%$. Sehingga dapat diketahui bahwa formula FC memiliki keseragaman yang paling baik dibandingkan dengan formula yang lain.

\section{Keseragaman ukuran tablet}

Diameter dan tebal rata-rata tablet parasetamol formula FA, FB dan FC adalah sama yaitu $8 \mathrm{~mm}$ dan $5 \mathrm{~mm}$, dengan standar deviasi yang sama yaitu 0. Hasil yang didapat menunjukkan bahwa ketiga formula tablet parasetamol tersebut memiliki standar deviasi yang kecil, berarti ketiga formula memiliki keseragaman ukuran yang baik.

Ketiga formula tablet parasetamol memiliki varian yang sama yaitu 0 , maka tidak perlu dilakukan uji varian. Sehingga dapat disimpulkan antara tablet parasetamol formula FA, FB dan FC tidak memiliki perbedaan yang bermakna dalam hal keseragaman ukuran. 

Sifat Fisik Tablet Parasetamol Secara Granulasi Basah

\section{Uji kekerasan tablet}

Data hasil uji kekerasan tablet dianalisis dengan uji ANAVA satu jalan, dan diperoleh hasil yang signifikan. Hal ini ditunjukkan dengan nilai signifikan 0,000 yang berarti lebih kecil dari 0,05 , sehingga bisa disimpulkan bahwa kekerasan tablet tiap formula memang berbeda bermakna. Hasil uji LSD kekerasan tablet formula FA, FB dan FC dapat dilihat pada Tabel 6.

Tabel 6. Hasil Uji LSD Kekerasan Tablet

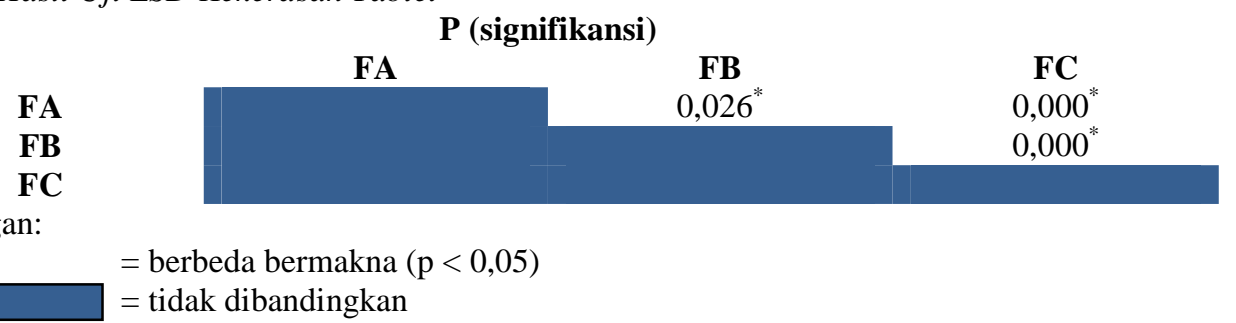

Hasil uji LSD kekerasan tablet antar formula tablet menunjukkan bahwa terdapat perbedaan bermakna antara formula FA dengan formula FB karena memiliki nilai signifikan $0,026(0,026<$ 0,05), formula FA dengan formula FC terdapat perbedaan yang bermakna karena memiliki nilai signifikan 0,000 $(0,000<0,05)$ dan formula FB dengan formula FC terdapat perbedaan yang bermakna karena memiliki nilai signifikan $0,000(0,000<0,05)$.

\section{Uji waktu hancur tablet}

Data hasil uji kekerasan tablet dianalisis dengan uji ANAVA satu jalan, dan diperoleh hasil yang signifikan. Hal ini ditunjukkan dengan nilai signifikan 0,000 yang berarti lebih kecil dari 0,05 , sehingga bisa disimpulkan bahwa kekerasan teblet tiap formula memang berbeda nyata. Hasil uji LSD waktu hancur antar formula dapat dilihat pada Tabel 7.

Tabel 7. Hasil Uji LSD Waktu Hancur Tablet

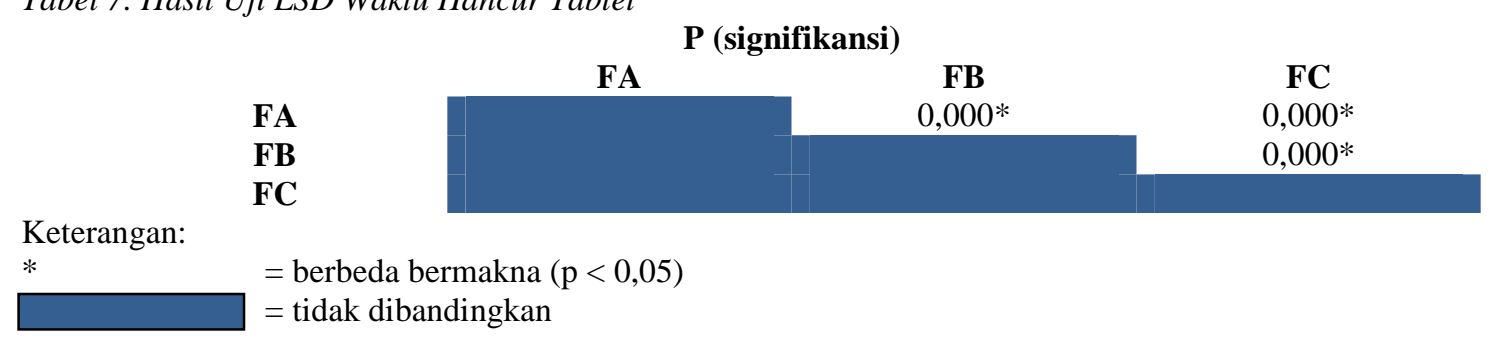

Hasil uji LSD waktu hancur antar formula tablet menunjukkan bahwa terdapat perbedaan bermakna antara formula FA dengan formula FB karena memiliki nilai signifikan $0,000(0,000<0,05)$, formula FA dengan formula FC terdapat perbedaan yang bermakna karena memiliki nilai signifikan $0,000(0,000<0,05)$ dan formula FB dengan formula FC terdapat perbedaan yang bermakna karena memiliki nilai signifikan $0,000(0,000<0,05)$.

Setelah dilakukan uji statistik menggunakan ANAVA dengan taraf kepercayaan (signifikansi penelitian) $\alpha=$ 0,05 maka terlihat ada perbedaan pada variasi keseragaman bobot, kekerasan tablet dan variasi waktu hancur antara tablet parasetamol formula FA, FB dan FC. 
Hasil dari ketiga uji fisik tersebut adalah saling berhubungan dalam tahap formulasi tablet, hal ini dapat dilihat dari hasil uji statistik ini. Terdapat perbedaan antara variasi keseragaman bobot, kekerasan tablet dan variasi waktu hancur tetapi tidak ada perbedaan variasi ukuran, hal ini menunjukkan bahwa volume cetakan dan tekanan pada saat kompresi tablet telah seragam, tetapi bobot tablet, kekerasan dan waktu hancur tablet yang dihasilkan masih bervariasi.

Diameter tablet formula FA, FB dan FC relatif konstan karena digunakannya punch dan die yang sama, begitu juga dengan ketebalan tablet. Ketiga formula menunjukkan keseragaman ukuran tablet yang hampir sama. Hal ini menunjukkan bahwa pada formulasi tablet parasetamol, bahan pengikat memiliki daya ikat terhadap massa tablet parasetamol, sehingga dihasilkan tablet dengan ukuran relatif sama.

Perbedaan variasi keseragaman bobot, kekerasan dan waktu hancur ini disebabkan oleh perbedaan konsentrasi pengikat pati biji cempedak, distribusi ukuran granul dan sifat alir granul yang kurang baik pada saat prakompresi.

Perbedaan penggunaan konsentrasi bahan pengikat pati biji cempedak sangat berpengaruh terhadap sifat fisik granul dan sifat fisik tablet. Makin besar konsentrasi pati biji cempedak, maka makin cepat waktu alir granul. Hal ini disebabkan karena semakin tinggi konsentrasi pengikat maka massa granul yang dihasilkan semakin baik, yaitu memberikan bentuk granul yang bulat atau tidak beraturan (hampir bulat) dengan permukaan yang halus sehingga mudah untuk mengalir. Peranan pengikat adalah untuk memberikan kohesivitas yang diperlukan untuk mengikat partikel-partikel padat, semakin besar konsentrasi pengikat, maka dapat meningkatkan pembesaran ukuran untuk membentuk granul sehingga dapat memperbaiki sifat aliran campuran selama proses pembuatan.

Meningkatnya konsentrasi bahan pengikat juga mengakibatkan kekuatan granul dan kekuatan tablet meningkat. Selama proses granulasi basah, pengikat membentuk matriks internal. Akibatnya kekuatan granul dan kekuatan tablet meningkat jika konsentrasi pengikat meningkat dalam formulasi. Jika konsentrasi pengikat meningkat, maka waktu hancur granul dan tablet meningkat.

Ikatan intragranular (dibentuk selama pengeringan granul) yang tidak pecah selama pengempaan, kohesi partikel dan pengikat, dan adhesi pengikat-pembawa adalah jenis ikatan yang berkontribusi pada kekuatan tablet (2).

Variasi dalam perbandingan granul kecil, granul besar dan variasi dalam besaran dari perbedaan ukuran granul mempengaruhi cara pengisian ruang celah antara partikelpartikel. Jadi, walaupun volume sebenarnya dalam die pada dasarnya sama, perbandingan (proporsi) partikel besar dan kecil yang berbeda dapat mengubah bobot isi dalam tiap die. Adanya perbedaan ukuran granul dapat menimbulkan variasi persentase bobot yang tinggi, juga mempengaruhi kekerasan dan waktu hancur tablet.

Sifat alir mempengaruhi proses pengisian cetakan (die). Bila aliran kurang baik, granul cenderung bergerak kembang kempis melalui alat pengisi, sehingga beberapa cetakan tidak terisi dengan sempurna. Hal ini menyebabkan terjadinya variasi bobot, kekerasan dan waktu hancur. Daya alir yang kurang baik ini dapat disebabkan oleh perbedaan ukuran partikel, 
getaran atau gerak mencampur dari peralatan untuk memperbaiki aliran mungkin menginduksi pemisahan dari partikel-partikel. Partikel yang lebih besar cenderung akan mengalir ke atas, sedangkan partikel kecil mengalir ke bawah. Ukuran partikel tidak hanya dapat menyebabkan perubahan berat serta variasi berat dari tablet, tetapi dapat juga menimbulkan ketidakseragaman isi atau kandungan, karena distribusi obat sering tidak merata antara partikel besar dan kecil. Selain itu, daya alir yang kurang baik ini juga disebabkan oleh penambahan bahan pelicin (glidant) pada granul yang tidak homogen.

Hasil penelitian ini menunjukkan bahwa penggunaan bahan pengikat pati biji cempedak dengan berbagai konsentrasi sangat mempengaruhi sifat fisik tablet. Pada penelitian ini digunakan pengikat pati biji cempedak dengan konsentrasi formula FA $6 \%$, formula FB $8 \%$ dan formula FC $10 \%$. Hasil evaluasi granul dan evaluasi tablet dari formula tablet dengan ketiga konsentrasi pengikat tersebut, maka formula yang menghasilkan granul dan tablet yang paling baik dan memenuhi persyaratan tablet adalah formula dengan konsentrasi pengikat $10 \%$, yaitu formula FC.

\section{KESIMPULAN DAN SARAN}

\section{A. Kesimpulan}

1) Dari penelitian ini dapat disimpulkan bahwa pati biji cempedak dapat digunakan sebagai bahan pengikat dalam pembuatan tablet parasetamol secara granulasi basah. Semakin tinggi konsentrasi pati biji cempedak yang digunakan, maka sifat fisik tablet yang dihasilkan semakin baik.

2) Pati biji cempedak dapat digunakan sebagai bahan pengikat tablet dan memberikan sifat fisik tablet yang baik pada konsentrasi $8 \%$ dan $10 \%$. Pada konsentrasi $8 \%$ menghasilkan tablet dengan bobot rata-rata $288,5 \mathrm{mg}(\%$ penyimpangan 4,33\%), kekerasan tablet $4,3 \mathrm{Kg} / \mathrm{cm}^{2}$ dan waktu hancur 3 menit 13 detik. Pada konsentrasi $10 \%$ menghasilkan tablet dengan bobot ratarata $299,8 \mathrm{mg}$ (\% penyimpangan $3,94 \%$ ), kekerasan tablet $5,6 \mathrm{Kg} / \mathrm{cm}^{2}$ dan waktu hancur 4 menit 27 detik.

\section{B. Saran}

Pada penelitian dan pengembangan selanjutnya sebaiknya dilakukan penelitian lebih lanjut, yaitu:

1) Mengoptimalkan proses pembuatan pati biji cempedak, sehingga menghasilkan pati biji cempedak yang baik dan selanjutnya dapat dikembangkan menjadi bahan tambahan sediaan farmasi.

2) Meneliti lebih lanjut kemampuan pati biji cempedak sebagai bahan pengikat pada pembuatan tablet dengan dilanjutkan sampai optimasi pembuatan tablet, uji disolusi dan uji ketersediaan hayati.

\section{UCAPAN TERIMA KASIH}

Kami mengucapkan terima kasih kepada Koordinator Kopertis Wilayah XI Kalimantan yang telah membiayai penelitian ini melalui DIPA Kopertis Wilayah XI tahun anggaran 2010.

\section{DAFTAR PUSTAKA}

1. Lachman L., Herbert A.L., and Joseph L.K. 1986. The Theory and Practice of Industrial Pharmacy. Philadelphia: Lea \& Febiger.

2. Siregar, C. J. P., 2010. Teknologi Farmasi Sediaan Tablet. Jakarta: Penerbit Buku Kedokteran. 
Pengaruh Penggunaan Pati Biji Cempedak (Arthocarpus Champeden Lour) Sebagai Bahan Pengikat Terhadap Sifat Fisik Tablet Parasetamol Secara Granulasi Basah

3. Agoes, G. 2008. Pengembangan Sediaan Farmasi. Bandung: Penerbit ITB.

4. Wade, A dan Weller, P.J (eds).1994. Handbook of pharmaceutical excipient. $2^{\text {nd }}$ ed. Washington: American Pharmaceutical Association.

5. Jufri, M., Dewi, R., Ridwan, A., Firli. 2006. Studi Kemampuan Pati Biji Durian Sebagai Bahan Pengikat Dalam Tablet Ketoprofen Secara Granulasi Basah. MIK. Vol. III no. 2. Hal. 78-86

6. Firmansyah, Deswita, Y., Ben, E.S. 2007. Ketersediaan Hayati Tablet Parasetamol Dengan Menggunakan Pati Nangka (Arthocarpus heterophyllus Lamk.) Sebagai Bahan Pembantu. JSTF. Vol. 12 no. 2.

7. Erna, Y., Widyastuti. 1993. Nangka dan Cempedak, Ragam, Jenis dan Pembudidayaan. Jakarta: Penebar Swadaya.

8. Anshari, H., Olenka, D., Marliana, M. 2010. Pemanfaatan Biji Cempedak Sebagai Alternatif Pengganti Tepung Terigu Dengan Kualitas dan Gizi Tinggi. Laporan Penelitian Program Kreativitas Mahasiswa. Universitas Negeri Malang. Malang.

9. Anonim. 1995. Farmakope Indonesia. Edisi IV. Jakarta: Departemen Kesehatan Republik Indonesia. 